\title{
JUVENILE DERMATOMYOSITIS CASES IN A NEW PEDIATRIC RHEUMATOLOGY CENTER IN NORTHEAST BRAZIL: A TEN-YEARS EXPERIENCE.
}

GABRIELA COUTINHO GONDIM DA JUSTA (HOSPITAL GERAL DE FORTALEZA, FORTALEZA, CE, Brasil), FRANCISCO AFRANIO PEREIRA NETO (HOSPITAL GERAL WALDEMAR DE ALCÂNTARA, FORTALEZA, CE, Brasil), EDUARDO CESAR RIOS NETO (HOSPITAL GERAL WALDEMAR DE ALCÂNTARA, FORTALEZA, CE, Brasil), ANA BEATRIZ ALMEIDA DA CUNHA (CENTRO UNIVERSITÁRIO UNICHRISTUS, FORTALEZA, CE, Brasil), REBECCA AZULAY MARTINS GONDIM (CENTRO UNIVERSITÁRIO UNICHRISTUS, FORTALEZA, CE, Brasil), LARISSA ELIAS PINHO (HOSPITAL GERAL DE FORTALEZA, FORTALEZA, CE, Brasil), MÍRIA PAULA VIEIRA CAVALCANTE (HOSPITAL GERAL DE FORTALEZA, FORTALEZA, CE, Brasil), MARCO FELIPE CASTRO DA SILVA (HOSPITAL GERAL DE FORTALEZA, FORTALEZA, CE, Brasil), CARLOS NOBRE RABELO-JUNIOR (HOSPITAL GERAL DE FORTALEZA, FORTALEZA, CE, Brasil)

\section{BACKGROUND}

Juvenile dermatomyositis (JDM) is the most common inflammatory myopathy in pediatric age group, characterized by systemic vasculopathy causing muscle weakness and typical skin changes. JDM diagnosis is clinical, aided by complementary exams. Treatment is based on early and aggressive immunosuppression, and disease course is variable. It is not related to neoplasia, unlike adult disease presentation.

\section{MATERIALS AND METHODS}

Retrospective, descriptive and observational cohort study, performed at pediatric rheumatology unit of a tertiary hospital in Ceará. Were evaluated patients medical records diagnosed with JDM by Bohan and Peter criteria, starting disease before 18 years-old, followed regularly from October 2009 to April 2019. Data were collected in May 2019 and analyzed by simple proportions.

\section{RESULTS}

A total of 13 patients were included, of which nine (69.2\%) were female. Median age at diagnosis and median time between symptoms onset and diagnosis were $9.6(2.6-17.3)$ and 1.3 years $(0-6.6)$ respectively, while median follow-up was 3.3 years $(1.2-11.8)$. Nine $(69.2 \%)$ cases were classified as definitive JDM and two as amyopathic form. Regarding disease features, muscle weakness and muscle enzymes elevation were described in 10 (84.6\%) cases. Electroneuromyography and muscle biopsy were performed in six (46.1\%) and nine (69.2\%) patients, respectively. Presence of calcinosis was reported in two (15.8\%) and chronic polyarthritis at disease onset in five (38.5\%) patients. Severe intestinal pneumatosis was detected in one case. At diagnosis, most common drugs used were prednisone (100\%), methotrexate (61.5\%) and hydroxychloroquine (46.1\%). During assessed period, one patient lost followup, eight $(61.5 \%)$ are on pediatric follow-up and four (30\%) were transferred to general rheumatology in same hospital. Of those who are followed, six (50\%) patients have achieved remission on medication, while six $(50 \%)$ persists with clinical-laboratory activity. The disease polycyclic course was the most prevalent $(61.5 \%)$.

\section{CONCLUSION}

Early diagnosis and aggressive treatment have great impact on disease prognosis, being essential the suggestive symptoms identification by pediatrician. Chronic polyarthritis, a clinical manifestation rarely described in JDM, was common in initial presentation in present study, and also responsible for relapses and refractory disease. Current treatment recommendations suggest early methotrexate introduction at diagnosis rather than corticosteroid monotherapy. Patients with polycyclic course usually present more severe disease and higher complications rate. 